\title{
Issues related to naturally aspirated and supercharged CI engines fueled with diesel oil and CNG gas
}

The study presents results of a research work on two various Diesel engines adapted for dual fuel feeding with CNG gas and diesel oil. The first engine is naturally aspirated, medium-sized engine, corresponding to engines mounted as power units in trucks and buses. Natural gas was used as the main fuel to this engine, and amount of diesel oil was reduced to minimum according to criterion of correct operation of injection system and reliable ignition of gaseous mixture. The second engine was a high-speed, supercharged engine of Fiat 1.3 MJT type, destined to powering of passenger cars. This engine is equipped with modern engine technologies, high-pressure injection system of Common Rail type with division of fuel dose and recirculation of exhaust gases, with catalytic converter and DPF filter. To fueling of this engine was used small additive of gas, aimed at reduction of smokiness of exhaust gases. Performed research has shown beneficial effect of gas on engine efficiency, reduction of concentration of nitrogen oxides, smokiness of exhaust gases and emission of particulate matter. Simultaneously, however, emissions of carbon monoxide and hydrocarbons had increased, especially in area of partial engine loads. Results of the study are pointing at possibility of installation of dual fuel system in traction engines with different size.

Key words: compressed natural gas, dual fuel engine, work parameters, toxicity, smoke, engine controlling

\section{Introduction}

In course of the recent decades, worldwide, it has been carried out intense research work on use of alternative fuels in relation to traditional, petroleum fuels $[1,11,17]$. It is connected with gradual scarcity of crude oil, diversification of energy sources, as well as environmental concerns. Such pursuit has resulted in legal regulations connected with gradual introduction of bio-fuels and gaseous fuels to combustion engines. Nowadays, ethyl and methyl alcohols, as bio-fuels, are used mainly in spark ignition engines, while processed fatty acid esters are used in Diesel engines as bio-fuels. Difficulties of blending simple alcohols with gasoline and diesel oil, and limited market supply of fatty acid esters, in Polish domestic conditions produced from rape oil, result in fact that anticipated future maximal market share will amount to $10 \%$ of total volume of consumed fuels. Use of gaseous fuels, mainly natural gas, bio-gases (of fermentation and landfill origin) and mine gas, belongs to completely different issue. Resources of natural gas, calculated energetically, are many times bigger than documented resources of crude oil, while degree of processing of the gas is significantly smaller, what have effects both on price of unit energy and total energetic loss. Use of waste, fermentation and mine gases is enforced by environmental reasons, because combustion of such gases in a torches or energetic boilers leads to environmental pollution and energy losses. Due to the above, it is anticipated that in the nearest future the CNG gas and the LNG gas will become the second fuel after liquid petroleum fuels, and their market share in European Union will reach level of about 20\% of total consumed fuels $[11,16]$. Nowadays, waste gases are used in co-generation systems, but emerging recently commercial installations to enrichment of methane in these gases can result in use of such gases in traction engines.

The natural gas, both CNG and LNG, can be used both in spark ignition and compression ignition engines [2, 3, 7]. Smaller-size automotive compression ignition engines operate mainly in bi-fuel system and can be alternatively fueled with gasoline or $\mathrm{CNG}$ gas, what results from limited network of CNG filling stations. In such engines the compression ratio remains unchanged due to need of fueling with gasoline. Bigger-size engines for powering of trucks and buses are built as adaptations of compression ignition engines to fueling with CNG or LNG gas. In such configuration the engines can operate according to spark ignition system or in so called Dual Fuel (DF) system with selfacting ignition of gaseous mixture [4-6, 8, 9].

In Dual Fuel Diesel engines, combustion process is initiated by self-ignition of small dose of liquid fuel. In majority of adaptations a small volume of initial dose is used, regardless of engine load [1, 4, 5, 7, 8, 11, 16, 17]. The aim is to minimize the initial dose, which due to considerable differences in price of liquid fuel and gas can lead to reduction of operational costs of the engines.

Issue of operational interchangeability of diesel oil with gas in DF engines can be analyzed from two points of view. In the first one, the CNG gas is considered as a main fuel, while quantity of consumed diesel oil results from reliable ignition of the gas only. Scope of adaptation of such engine should be significant; fueling with neat diesel oil can be treated as emergency fueling in case of shortage of gas or breakdown of gaseous installation. In the second case, quantity of gaseous fuel is small and the main objective is to reduce smoke of exhaust gases when the engine is operated in adverse urban conditions [10, 12-14, 19-21]. Scope of the adaptation in such case is significantly smaller, and the engine can be run alternatively on neat diesel oil or fueled in DF system [22, 23]. With such approach, the DF system can be implemented even in small-sized, high-speed automotive engines. With both types of the adaptation, compression ratio remains on unchanged level, what have beneficial effect on conditions of self-ignition of diesel oil and engine efficiency.

In dual fuel engine, it is important to maintain correct quality of charge, what will assure reliable ignition of gasair mixture and correct course of its combustion. Quality of the charge is affected by size of initial dose and composition of gas-air mixture. At constant initial dose, reduction of 
engine load occurs by reduction of quantity of gas. This results in leaning of the gas-air mixture, leading to worsening of combustion rate of the mixture, what effects in reduction of overall engine efficiency and increase of emissions of carbon monoxide and unburned hydrocarbons [7, 9, 11, 16]. Widespread use of Common Rail systems to liquid fuel injection can facilitate, to some extent, problems with excessive leaning of gaseous mixture, but can generate additional difficulties connected with advantages of division of the dose $[21,23]$. The gas-air mixture is ignited by the first initial dose, Pilot or Pre dose, which determines course of entire combustion process. For this reason, initial dose should be injected with an advance suitable to combustion of gaseous mixture, considerably later relative to run on neat diesel oil. Too early advance angles of initial doses, what occurs when liquid fuel dose is divided, have unfavorable effect on combustion of gaseous mixture. On the other hand, too late injections of big dose of liquid fuel during advanced combustion process of gaseous mixture results in worsening of combustion conditions of liquid fuel [23].

Maintaining the correct quality of the charge depends also on whether the adaptation is made on naturally aspirated or supercharged engine. Leaning of gaseous mixture in naturally aspirated engine is caused by reduction of engine load, what distinctly affects worsening of combustion process. Situations of misfire can occur at extreme leaning of gaseous mixture, what affects worsening of smoothness of engine operation $[2,3,6,8,16]$. In supercharged engines, maintaining correct composition of gaseous mixture can be partially achieved by changed ratio of supercharging.

In the presented study are depicted results of research work on dual fuel, medium-sized, naturally aspirated engine (size of cylinders corresponds with engines used in trucks and buses) and high-speed supercharged engine to passenger cars. In the first investigated engine, the CNG gas was used as the main fuel, in the second engine the CNG gas was used as additive, reducing smokiness of exhaust gases. Comparison of the test results of these different fueling concepts and different engines can be helpful in taking decisions about use of dual fuel systems in traction engines.

\section{Engine test bed}

The tests were performed on a single-cylinder experimental engine of SB3.1 type with compression ignition and direct injection system, produced by WSK Mielec, and on automotive engine of Fiat 1.3 MJT type manufactured by Fiat-GM plant in Bielsko-Biała.

In the SB3.1 engine it were used Common Rail system to injection of diesel oil, and injection system of gas to inlet manifold located near aspiration valve. The both electronically controlled systems, allowed for free shaping of doses size and fuel shares according with assumed criteria of fueling and optimization of parameters. View of the test bed and the SB3.1 engine after the adaptation is presented in the Fig. 1, while technical parameters of this engine are listed in the Table 1.

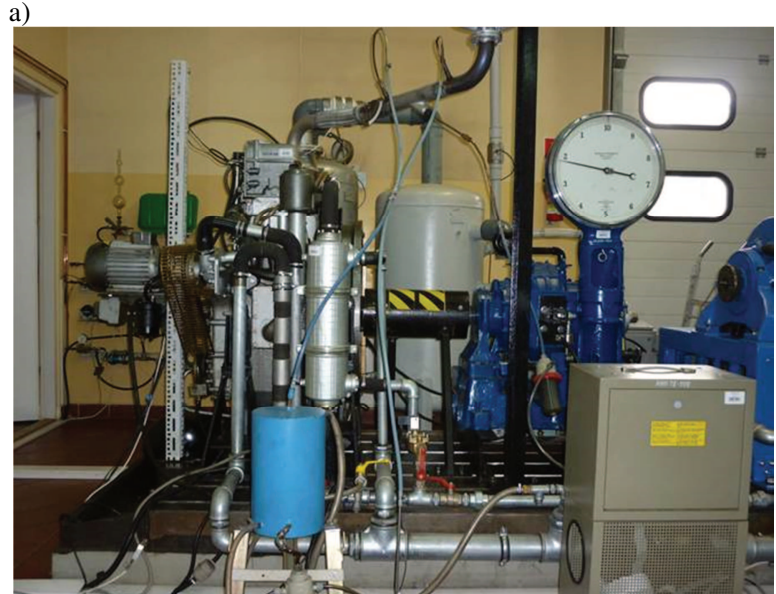

b)

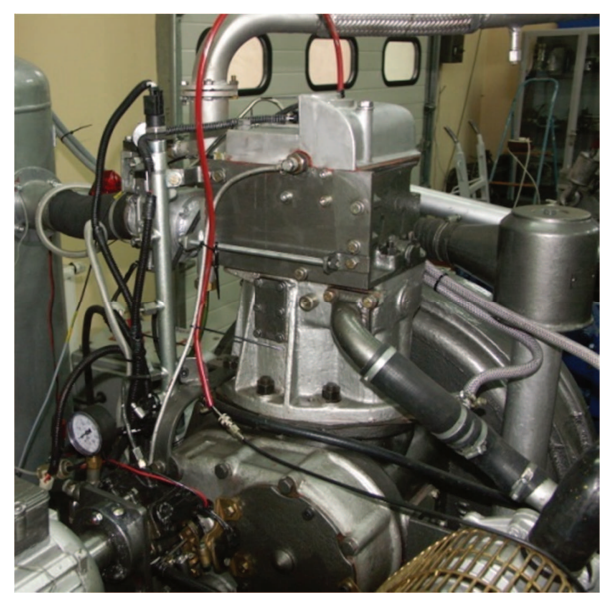

Fig. 1. General view of the test bed: a) engine test bed, b) view of the engine with assembled Common Rail system and with gas injectors on inlet manifold

Table 1. Technical data of of SB3.1 engine

\begin{tabular}{|l|c|}
\hline Number of cylinder & 1 \\
\hline Bore x stroke & $127 \times 146 \mathrm{~mm}$ \\
\hline Displacement & $1848 \mathrm{~cm}^{3}$ \\
\hline Compression ratio & 15.8 \\
\hline Maximum power/Engine revolution & $22.8 \mathrm{~kW} / 2200 \mathrm{rpm}$ \\
\hline Type of combustion chamber & $\begin{array}{c}\text { Direct injection } \\
\text { Toroidal combustion chamber } \\
\text { in the piston }\end{array}$ \\
\hline Injection system & Common Rail f-my Bosch \\
\hline Injector Bosch & 0986435004090 \\
\hline Injection system of CNG & IC \\
\hline Gas injector Bosch & F465 15172 \\
\hline Gas injection pressure & $1 \mathrm{MPa}$ \\
\hline
\end{tabular}

As the second engine was used in the investigations compression ignition, supercharged, four cylinder engine of FIAT 1.3 MJT type with swept capacity of $1248 \mathrm{ccm}$. Direct fuel injection in this engine was accomplished by second generation Common Rail system, so called Multi Jet. The engine was adapted to dual fuel operation in the Department of Combustion Engines and Vehicles in the ATH in Bielsko-Biała. Technical parameters of the engine are presented in the Table 2. 
Table 2. Technical specification of Fiat 1.3 MJT engine [24]

\begin{tabular}{|l|c|}
\hline Engine type & $1.3 \mathrm{MJT}$ \\
\hline Bore x stroke & $69.6 \times 82 \mathrm{~mm}$ \\
\hline Displacement & $1248 \mathrm{~cm}^{3}$ \\
\hline Number of cylinder & 4 \\
\hline Compression ratio & 18 \\
\hline Maximum power & $51 \mathrm{~kW}$ at $4000 \mathrm{rpm}$ \\
\hline Maximum torque & Common Rail \\
\hline Injection system & 4 \\
\hline Number of valve per cylinder & DOHC \\
\hline Timing system & EGR valve \\
\hline Exhaust gas recirculation & \\
\hline
\end{tabular}

a)

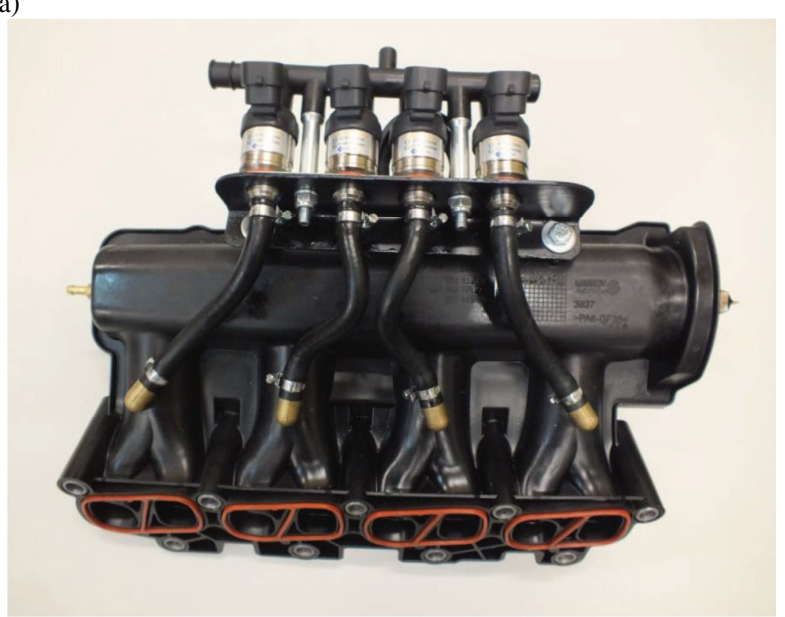

b)

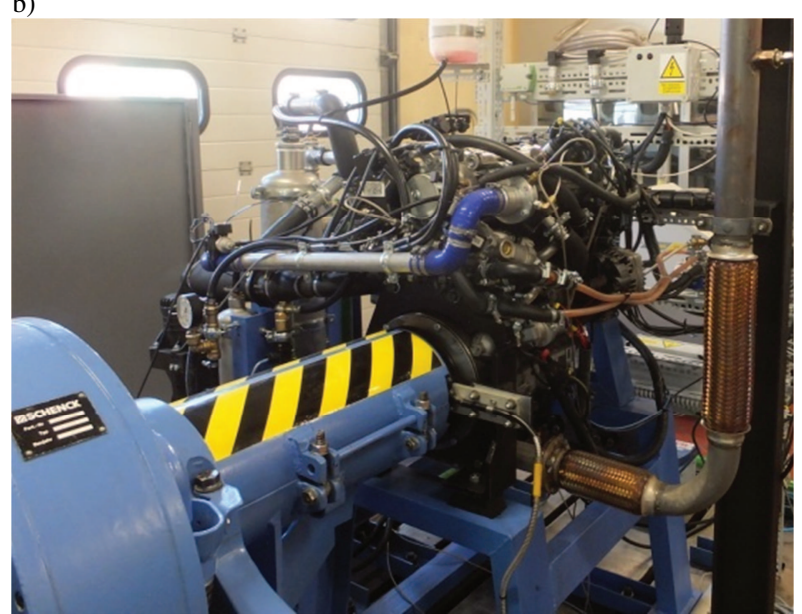

Fig. 2. Intake manifold and test stand of Fiat 1.3 MJT engine:a) intake manifold, b) test stand

Control of the dual fuel engine was performed by factory made electronic control unit (ECU) of MJD.6F3 type produced by Magneti Marelli. When adding the gas, the ECU controller automatically reduces dose of diesel oil to maintain required engine torque. With considerable changes in unit dose of diesel oil, output of the air is also reduced.

\section{Analysis of the test results}

In dual fuel, naturally aspirated engine, in which CNG gas is the main fuel, constant initial dose is used, size of this dose is determined by reliable ignition of gas. With maintained condition of engine operation on neat diesel oil, or in dual fuel operation, original injectors are not replaced as a rule, what means that possible minimal dose is usually bigger than the dose required to reliable ignition of gas.
This results in lower interchangeability of diesel oil with gas. Changes in engine load are obtained by reduction of amount of gas (reduction of opening time of gas injectors) what results in leaning of gaseous mixture and reduction of share of gas at partial engine loads, Fig. 3a. The biggest share of gas is present at maximal engine load; in case of tested SB3.1 engine such share amounted to $80-85 \%$, depending on engine speed, Fig. 3a.

a)

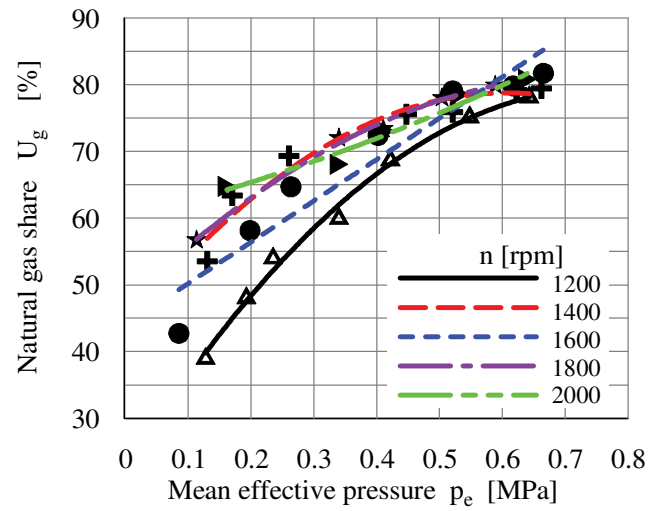

b)

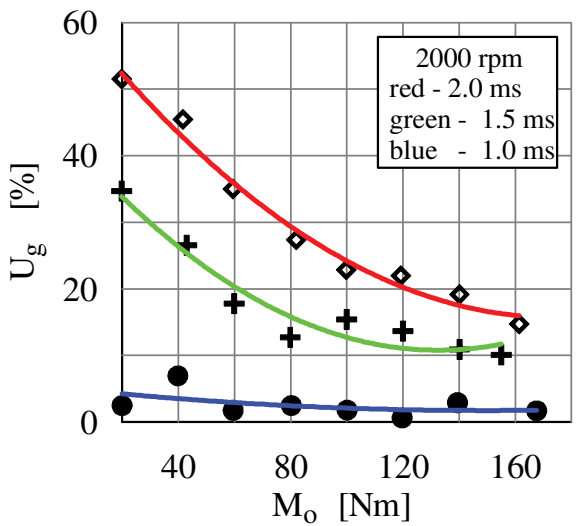

Fig 3. Influence of engine load on energetic share of gas in total dose of energy supplied to the engine: a) SB3.1 engine, different engine speeds, initial dose $\mathrm{q}=19.8 \mathrm{~mm} 3 / \mathrm{cycle}$, injection advance angle 22oCA before TDC; b) Fiat 1.3 MJT engine, variable opening time of gas injectors, constant pressure of gas 4.5 bar

A different situation occurs in supercharged engine with small addition of gas, while change in engine load was accomplished by reduction of total dose of diesel oil. Small shares of gas were obtained at full engine load, while a bigger ones at partial loads, Fig. 3b. In the engine of Fiat 1.3 MJT type, for opening time of gas injectors of $2 \mathrm{~ms}$, at low engine loads it has been obtained energetic share of gas in range of $40 \div 50 \%$, while in case of maximal load of about $15 \%$. In supercharged engine, reduced engine load is accompanied by reduced ratio of supercharging, what at constant amount of gas results in enrichment of gaseous mixture and improvement of conditions of its combustion. As automotive engines in majority of their operational life are running at partial engine loads, course of interchangeability of fuels shown in the Fig. $3 \mathrm{~b}$ is favorable in terms of increased operational interchangeability of diesel oil, and improved ecological features of the engine. It concerns especially a cars running in big cities. 
Use of gaseous fueling in naturally aspirated engine can lead to reduction of maximal brake power with $8 \div 10 \%$, what can discourage to gaseous fueling. Engines which require maintained rated brake power at engine load of 90 $100 \% \mathrm{~N}_{\text {ezn }}$ should be run on neat diesel oil. Additional argument for such concept is fact that modern traction engines feature high compression ratios and high ratios of supercharging. In some engines this promotes occurrence of knocking combustion when the engine is run on gas with minimal initial dose. Moreover, keeping the brake power on unchanged level requires reduction of average excess air factor $\lambda$, what can lead to thermal overloading of the engine.

In modern dual fuel engines are preferred Common Rail type injection systems of liquid fuel and multipoint injection of gas to inlet manifold. The both systems, controlled electronically, facilitate maintaining of proper composition of charge in any point of engine operation, and enable automatic change-over of operational mode of the engine (traditional or dual fuel) independently on will of a driver. With such systems it is possible to use such ranges of traction engine operation as shown in the Fig. 4. Due to small portion of time when traction engine is operated at maximal loads, use of traditional fueling system shouldn't have any significant effect on reduction of interchangeability of liquid fuel with gas. In engines for which reduction of maximal brake power is acceptable to customers, dual fuel feeding can be accomplished within range of engine load change of $20-100 \%$.

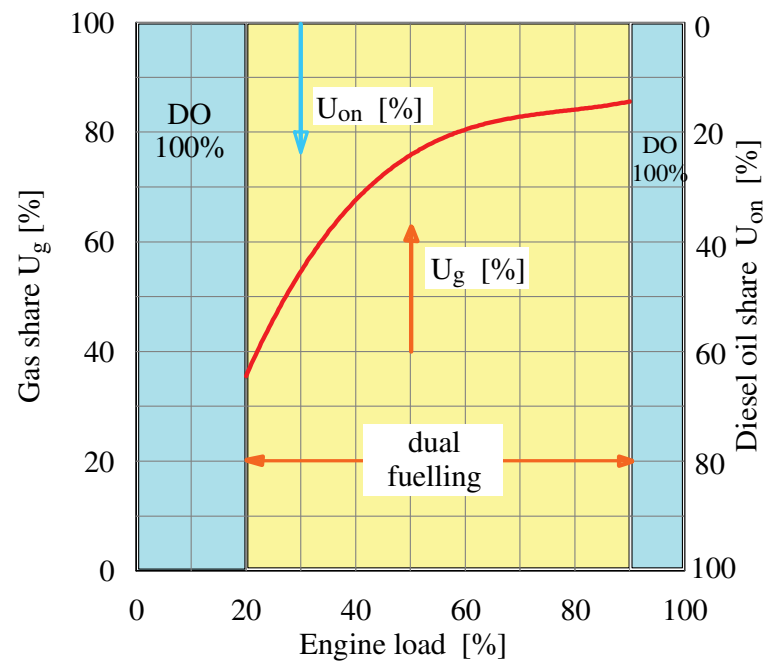

Fig. 4. Proposed range of gaseous fueling in dual fuel traction engine [18]

Dual fuel feeding advantageously affects engine efficiency in range of maximal loads, when the engine is run on rich gaseous mixture. Composition of gaseous mixture depends on size of initial dose, while maintaining the same $\mathrm{M}_{\mathrm{oDO}}=\mathrm{M}_{\mathrm{oDF}}$ engine load, the gaseous mixture undergoes enrichment as the initial dose decreases. In the tested engine of SB3.1 type for the dose of $\mathrm{q}=14.6 \mathrm{~mm}^{3} /$ cycle at maximal engine load, overall efficiency increased in complete range of change of engine speed, Fig. 5a. Absolute growth of the efficiency has amounted to $0.9-2.1 \%$, depending on engine speed. a)

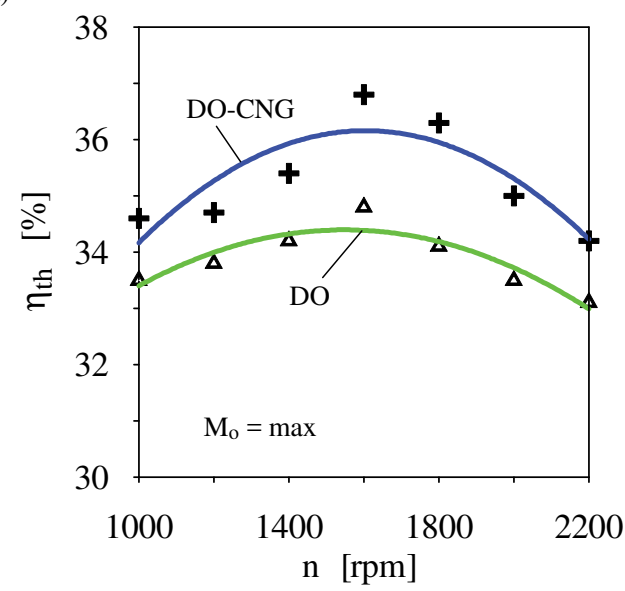

b)

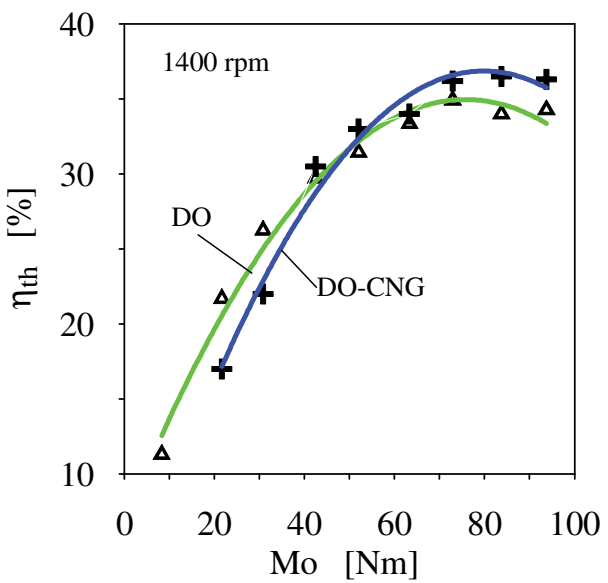

Fig. 5. Comparison of overall efficiency of SB3.1 engine run on diesel oil (DO) and in dual fuel system run on diesel oil and CNG gas (DO-CNG): initial dose $\mathrm{q}=14.6 \mathrm{~mm}^{3} /$ cycle

Comparison of the efficiency shown in the Fig. 5b indicates that increase of efficiency occurs for a higher loads, in range of engine torque $>0.5 \cdot \mathrm{M}_{\mathrm{omax}}$. With low engine loads, excessive leaning of gaseous mixture leads to prolonged time of its combustion, what results in reduction of the efficiency. As a result, overall efficiency of dual fuel engine is lower than efficiency of the engine run on neat diesel oil.

In the engine controlled electronically, quantity of supplied gas can be adjusted by change of opening time of gas injector. In modern engines with Common Rail injection system and with original controller, small additive of gas, amounting to $25-35 \%$ of energetic share, doesn't change division method of diesel oil dose. Therefore, in the controllers to dual fuel engines it is possible to make use of control algorithms from traditionally fueled engine, only size of the main doses should be suitably corrected.

In the tested Fiat 1.3 MJT engine, at constant gas pressure of 1 bar in range of short opening time of the injectors 0-2 ms, gas outflow is small, what assures shares of gas smaller than about $5 \%$. This is probably due to inertia of assembled gas injectors, which are not entirely open in case of such short times, but also results from inertia of stream of gas. Only for opening times longer than $3 \mathrm{~ms}$, a distinct increase in share of gas in total energy supplied to the engine can be seen, Fig. 6a. 
Amount of gas addition has significant effect on concentration of toxic components of exhaust gases emitted from Fiat 1.3 MJT engine, especially advantageously affects $\mathrm{NO}_{x}$ concentrations. Addition of $30 \%$ of gas resulted in nearly twice reduction of $\mathrm{NO}_{\mathrm{x}}$ in exhaust gases of the investigated engine, Fig. 6b. Simultaneously, however, concentrations of carbon monoxide and unburned hydrocarbons increase. At 30\% additive of gas, increase of concentration of $\mathrm{CO}$ was nearly fourfold, and aggregated hydrocarbons nearly eightfold, Fig. 6b. It is worth underlining, however, that in supercharged engines with indirect injection of gas to inlet manifold, a part of hydrocarbons enters into exhaust system due to valve overlapping. The main component of measured hydrocarbons is methane, considered as harmless, but having impact on greenhouse effect, similarly like $\mathrm{CO}_{2}$.

a)

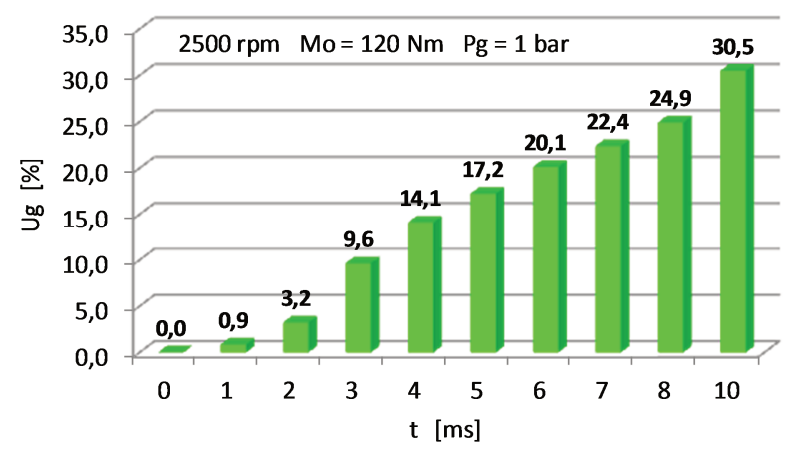

b)

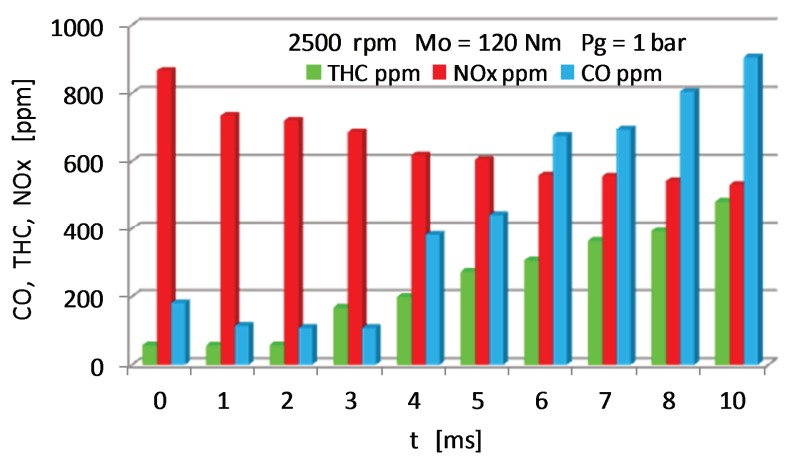

Fig. 6. Changes the gas energy share $U_{g}$ and the concentration toxic components of exhaust gases of engine Fiat 1.3 MTI depending on gas injectors opening time: fixed gas supply pressure 1 bar

During testing of Fiat 1.3 MJT engine it had been used original ECU controller from this engine running on neat diesel oil. With small addition of gas at constant openings of gas injectors, $1.5 \mathrm{~ms}$ and $2.0 \mathrm{~ms}$, controlling algorithms of diesel oil injection (method of division of the dose and angle of beginning of their injection) remained unchanged. Only size of the main doses was changed, they were decreased proportionally to quantity of energy supplied with gas. This affected course of toxic components concentration in exhaust gases according to engine load, what is shown in the Fig. 7.

Additive of gas almost in complete range of engine load change results in increased concentration of carbon monoxide and aggregated hydrocarbons (Fig. 7a and 7b), and decrease in concentration of nitrogen oxides, Fig. 7c.

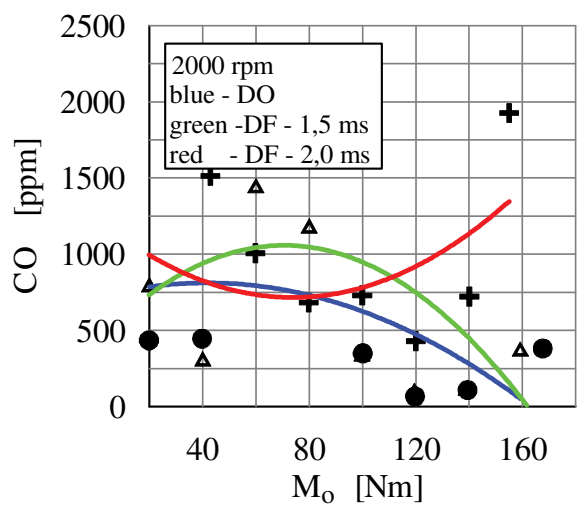

b)

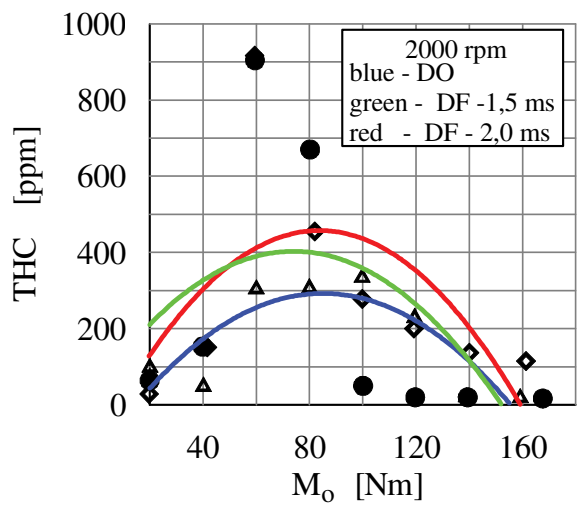

c)

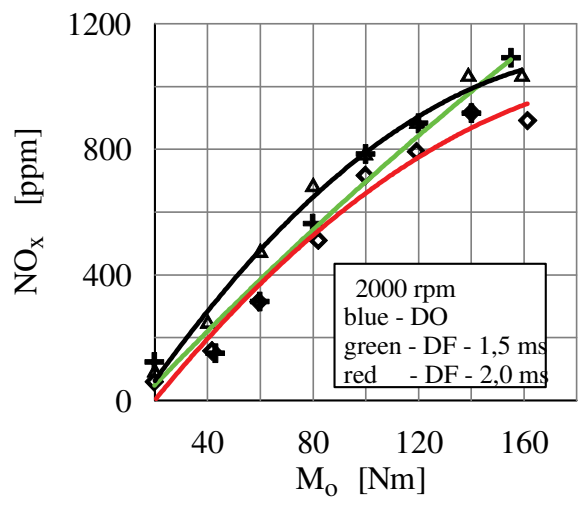

Fig. 7. Comparison the concentration of toxic component in exhaust Fiat 1.3 MJT engine fuelled with diesel oil and dual fuel for varies times of gas injectors opening: engine speed $2000 \mathrm{rpm}$, times of gas injectors opening $1.5 \mathrm{~ms}, 2.0 \mathrm{~ms}$

In testing of modern passenger cars are performed measurements of toxic components of exhaust gases under conditions equivalent to driving conditions on road, i.e. at changing engine speed, load and time. Such tests are performed on chassis dynamometer, in European countries according to NEDC cycle. In the tests discussed in this paper, 20 points of static engine operation on engine dynamometer in conditions of ( $\mathrm{n}, \mathrm{M}_{\mathrm{o}}=$ const) were used, simulating the NEDC road test. During selection of these points were used methods of static analysis described in the study [15].

Effect of additive of gas on smokiness of exhaust gases and emission of particulate matter was discussed basing on comparison with traditional fueling in these 20 selected points, simulating NEDC test. 
To measurement of smokiness of exhaust gases it was used opacimeter made by AVL, model 415 SE, with FSN (Filter Smoke Number) scale or $\mathrm{mg} / \mathrm{m}^{3}$ scale. Size of particulate matter was measured with use of 3090 EEPS (Engine Exhaust Particle Sizer ${ }^{\mathrm{TM}}$ Spectrometer) analyzer produced by the TSI Incorporated Company. The analyzer had enabled analysis of continuous dimensional distribution of particulate matter emitted by the engine. The spectrometer enabled measurement of particulate matter's size in range of 5.6-560 nm of their diameter (22 measuring channels) with frequency $10 \mathrm{~Hz}$.

In the Fig. 8 is presented effect of addition of gas in range of $24.6-35.6 \%$ of energetic share on reduction of smokiness of exhaust gases. It should be underlined that in case of dual fuel feeding a correction of boost factor was used so that air excess ratio was the same as for traditional fueling. The smokiness of exhaust gases underwent reduction in nearly all tested points.

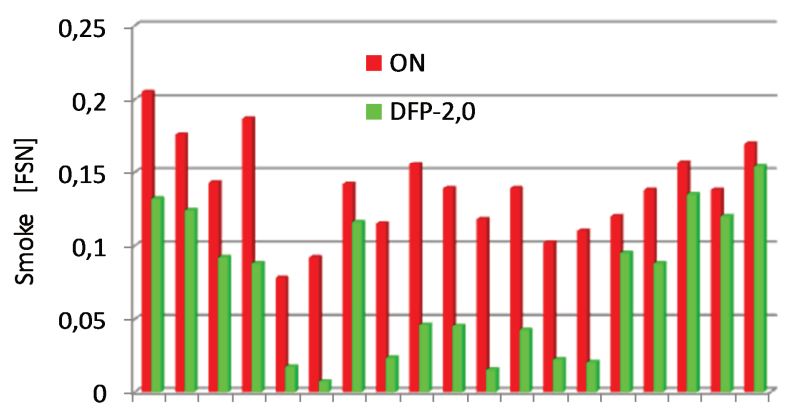

$\begin{array}{llllllllll}1 & 2 & 3 & 5 & 6 & 7 & 8 & 9 & 1011 & 121314151617181920\end{array}$ Number of operating point according to the test NEDC

Fig 8. Comparison of smokiness of exhaust gases of Fiat 1.3 MJT engine fueled traditionally and in dual fuel system with correction of output of air air output at duel fuel feeding was the same as at fueling with diesel oil, opening time of gas injectors $2.0 \mathrm{~ms}$

Emission of particulate matter (PM), due to their hygroscopicity and density lower than density of air, is a serious hazard for the environment and generates important problems of modern compression ignition automotive engines $[1,13,17,20]$. For this reason, during the last two decades, emission of the PM was the most intensively reduced, comparing to other toxic components of exhaust gases. Contemporary legal regulations restrict not only mass emissions of the particulate matter expressed in $\left[\mathrm{mg} / \mathrm{m}^{3}\right]$, but also their PN number $[13,20]$. It results from the fact that together with high number of emitted particulates, percentage of the particulates with small diameter increases, what according to opinion of epidemiologists is particularly dangerous for living organisms, because small particulate matter can stay in atmosphere much longer than particulate matter with a bigger size. For this reason, emissions of particulate matter, considering their PN number and fractional distribution, were also measured in course of the research at the points corresponding to NEDC test.

From comparison shown in the Fig. 9 it is seen that in dual fuel feeding, almost in all investigated measuring points also total number of emitted particulate matter is lower than emissions in case of traditional fueling.

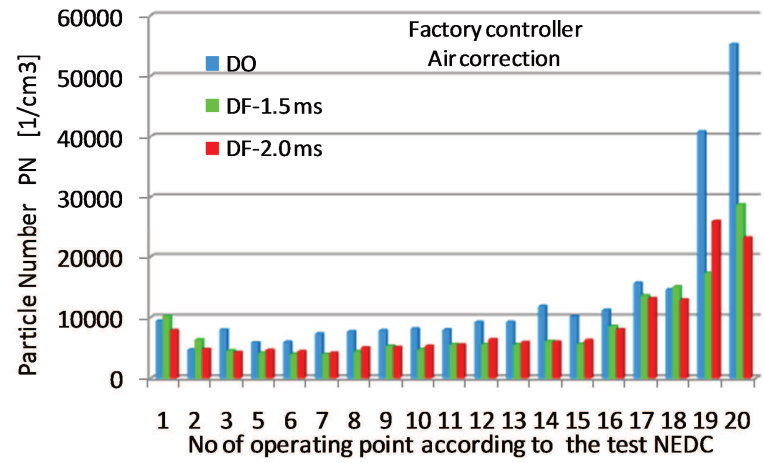

Fig 9. Comparison of total number of particulate matter (PN) in exhaust gases of Fiat 1.3 MJT engine fueled traditionally and in dual fuel system, with correction of air output: factory made ECU controller, constant opening time of gas injectors $1.5 \mathrm{~ms}$ and $2.0 \mathrm{~ms}$

It is also worth noting, that in a big number of measuring points, differences in number of emitted particulate matter for opening time of injectors equal $1.5 \mathrm{~ms}$ and 2.0 $\mathrm{ms}$ are small, while in some points even for the time of 2.0 $\mathrm{ms}$, number of the particulate matter is bigger than for the time of $1.5 \mathrm{~ms}$. Simultaneously, in all analyzed points the smokiness of exhaust emissions for the time of $2.0 \mathrm{~ms}$ was distinctly lower than the smokiness for the time of $1.5 \mathrm{~ms}$. It can therefore be assumed that at such points increased share of gas leads to emission of bigger number of particulate matter with small sizes.

Fundamental differences in quantity of emitted particulate matter for dual fuel feeding refer to particulate matter with average size, Fig. 10. In range of small and big particulate matter, quantities of emitted particulate matter for the both fueling systems are comparable.

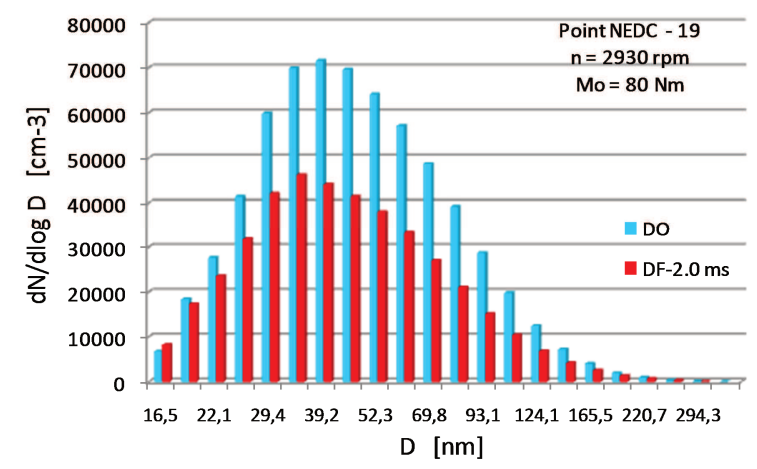

Fig 10. Comparison of fractional distribution of particulate matter $\mathrm{dN} / \mathrm{d} \log \mathrm{D}$ of the Fiat 1.3 MultiJet engine fueled traditionally and in dual fuel system: point 19 according to NEDC test, $\mathrm{n}=2930 \mathrm{rpm}$, $\mathrm{Mo}=80 \mathrm{Nm}$, opening time of gas injectors $2.0 \mathrm{~ms}$

\section{Summary}

The study performed on two engines: medium-sized, naturally aspirated engine similar to engines as mounted to trucks and buses, and high-speed supercharged engine destined to passenger cars, has enabled to draw a generalnature conclusions concerning both strategy of dual fuel supply and effects of such supply on engine performance.

- Controlling strategy of dual fuel engine depends on whether full interchangeability of fuels is assured - traditional fueling with diesel oil or in dual fuel system. Maintaining this condition, it is essential to remain un- 
changed components of serial injection system of the engine, which limits value of minimal initial dose and reduces interchangeability of diesel oil with gas. This applies both to engines equipped with inline, piston-type pumps as well pumps as used in Common Rail injection systems.

- For medium-sized traction engines, during period of introduction of gaseous fueling systems and shortage of CNG filling stations, complete interchangeability of the fuels should be absolutely assured. With assumption that CNG gas is the main fuel, minimal doses to be used will depend on injection systems of liquid fuel. For the sake of correct engine operation and proper operational life of injectors, the minimal doses shouldn't be smaller than:

$-20 \%$ of nominal dose for piston-type pumps,

$-15 \%$ of nominal dose for Common Rail systems.

- Application of the above mentioned doses enables, in conditions of engine load higher than $20 \%$ of its nominal torque, interchangeability of liquid fuel in scope of $40 \div 80 \%$ for piston-type pumps, and $55 \div 85 \%$ for Common Rail systems. Due to considerable difference in price of the fuels, engine adaptation is profitable both in case of already operated older engines, as well as modern engines with electronic injection systems of liquid fuel.

- Due to worsened combustion conditions of lean mixture in traction engines, the engine should be fed with neat diesel oil when the engine load is lower than $20 \%$ of rated load. This will allow reduction of $\mathrm{CO}$ and $\mathrm{THC}$ emissions and will improve overall efficiency of the engine.

- In medium-sized engines controlled electronically, with dual fuel systems and with assumption that CNG gas is the main fuel, maximal brake power of the engines should be limited to about $90-95 \%$, what results from needs of unchanged durability of injection equipment and condition of non-thermal overloading of the engine. In engines where the maximal brake power should be maintained at engine loads higher than $90 \%$, the engine should be supplied with neat diesel oil. Interchangeability of liquid fuel with gas will depend on method of engine operation. However, due to small percentage of minimal and maximal loads in total time of engine operation, interchangeability of liquid fuel shouldn't be significantly reduced.

- Supply of gas should be correlated with closing time of exhaust valve. Long opening times of gas injectors could impede to meet such condition at higher rotational speeds. In systems with injection of gas to inlet manifold, quantity of gas supplied to the engine can be adjusted by opening time of injectors and pressure of gaseous supply. In tested Fiat 1.3 MJT engine, at supply pressure of 1 bar, obtaining 30\% share of gas required opening time of injectors of about $4 \mathrm{~ms}$ at average en- gine loads, and about $10 \mathrm{~ms}$ at maximal loads. Use of higher supply pressures of gas enables considerable reduction of required injection time of the gas. The investigations have shown that at supply pressure of 4.5 bar, opening time of injectors equal to $2.0 \mathrm{~ms}$ has allowed obtainment of about $20 \%$ of energetic share of gas at maximal engine load in complete range of variations of engine speed.

- It seems that for engines in which gaseous fuel is not used as the main fuel, it is possible to implement constant opening times of gas injectors, set on the base of assumed share of gas at maximal engine load. Increasing share of gas at partial engine loads promotes interchangeability of liquid fuel with gas in traction engines, and reduces running costs of the engine. Investigations of Fiat 1.3 MJT engine have shown that this engine can operate correctly in range of partial engine loads with share of gas of about $60 \%$.

- Original ECU controller optimized to fueling with diesel oil in presence of gas causes reduction of boost pressure according to reduction of diesel oil dose. As a result, unit air dose per single engine cycle decreases. At comparable doses of energy supplied to engine together with diesel oil and gas, this negatively affects combustion process and results in increased $\mathrm{CO}$ and THC emissions, and emission of smoke in exhaust gases. This requires changed setting values of ECU controller, adjusting boost pressure, requires special control algorithms for dual fuel supply, and controllers adapted to such type of fueling.

- Small additive of CNG gas to diesel oil has effect on reduction of smokiness of exhaust gases and emission of particulate matter in modern automotive engines with Common Rail injection systems. Reduction of smokiness of exhaust gases amounted to $12-92 \%$, reduction of total number of particulate matter amounted to 30$40 \%$, depending on operational conditions of the engine. Especially important is reduction of particulate matter at a higher engine speeds and high engine loads, when emission of exhaust gases is the highest.

- Dual fuel supply in modern compression ignition engines can contribute to reduction of particulate matter emissions, especially in urban traffic conditions. This should result in increased intervals between subsequent regenerations of DPF filters, increased life of the filters and improved reliability of automotive engines.

\section{Acknowledgment}

The study was performed within framework of Research Project No. PBS1/A6/13/2012 „Reduction of smoke and particulate matter in exhaust gases of automotive engines with compression ignition, accomplished with use of CNG gas addition" financed by NCBiR.

\section{Bibliography}

[1] BARroso, P., RIBAS, X., DOMINGUES, J., et al. Study of dual-fuel (diesel+natural gas) particle mater and $\mathrm{CO}_{2}$

emissions of a heavy-duty diesel engine during transient operation. Combustion Engines. 2013, 153(2), 28-39.

[2] BEROUN, S., BLAŻEK, J. The possibility of the improvement of the combustion process stability in gas engines. VI 
Międzynarodowa Konferencja Gazowa "SILNIKI GAZOWE 2003", Częstochowa 2003.

[3] BEROUN, S., MARTINS, J. The development of gas (CNG, LPG and H2) engines for buses and trucks and their emission and cycle variability characteristics. SAE Technical Paper. 2001, 2001-01-0144.

[4] Clark, N.N., Atkinson, C.M., Atkinson, R.J. et al. Optimized emission reduction strategies for dual fuel compression ignition engines running on natural gas and diesel. www.cemr. wvu.edu, 2002, 1-6.

[5] Daisho, Y., Takahashi, K. Controlling combustion and exhaust emissions in a direct-injection diesel engine dual fueled with natural gas. SAE Technical Paper. 1995, 952436.

[6] EHSAN, M., BHUIJAN, S. Dual fuel performance of a small diesel engine for applications with less frequent load variations. International Journal of Mechanical \& Mechatronics Engineering. 2011, 9(10).

[7] FRIEDEMAN, Z. Gasmotoren. Vogel Buchverlag Wurzburg, 2001

[8] GEBERT, K., BECK, J., BARKHIMER, R.L., WONG, H.C. Strategies to improve combustion and emission characteristics of dual-fuel pilot ignited natural gas engines. SAE Technical Paper. 1997, 971712.

[9] KOWALEWICZ, A. Adaptacja silnika wysokoprężnego do zasilania gazem naturalnym. Czasopismo Techniczne Wydawnictwo Politechniki Krakowskiej. 2008, 7, 67-78.

[10] KOZAK, M. Studium wpływu komponentów tlenowych oleju napędowego na emisję toksycznych składników spalin z silników o zapłonie samoczynnym. Monografia habilitacyjna. Wydawnictwo Politechniki Poznańskiej, 2013.

[11] MATYJASIK, M. Aktywizacja procesu spalania mieszaniny gaz-powietrze $\mathrm{w}$ silnikach dwupaliwowych przez podział dawki inicjującej oleju napędowego. Praca doktorska, Bielsko-Biała 2012.

[12] MERKISZ, J., DASZKIEWICZ, P., IDZIOR, M., et al. Analiza ograniczenia emisji toksycznych składników spalin dwupaliwowego silnika o zapłonie samoczynnym. Logistyka. 2014, 6, 7260-7269.

Prof. Zdzislaw Stelmasiak, DSc., DEng. - Faculty of Mechanical Engineering and Computer Science at University of Bielsko-Biala.

e-mail: ZStelmasiak@ath.bielsko.pl

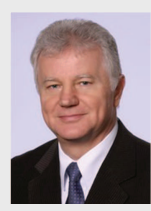

Jerzy Larisch, DEng. - Faculty of Mechanical Engineering and Computer Science at University of Bielsko-Biala.

e-mail:JLarisch@ath.bielsko.pl
[13] MERKISZ, J., PIELECHA, J. Emisja cząstek stałych ze źródeł motoryzacyjnych. Wydawnictwo Politechniki Poznańskiej. Poznań 2014.

[14] MERKISZ, J., PIELECHA, J., ŁABĘDŹ, K., STOJECKI, A. Badania emisji spalin pojazdów o różnej klasie emisyjnej zasilanych gazem ziemnym. Prace Naukowe Politechniki Warszawskiej. Transport. 2013, 98, 463-472.

[15] PIETRAS, D., SOBIESZCZAŃSKI, M., ŚWIĄTEK, A., PAJDOWSKI, P. Dobór parametrów pracy silnika 1.3 multijet charakterystycznych dla testu jezdnego NEDC do badań rozwojowych. PTNSS Kongres P05-C065, 2005.

[16] STELMASIAK, Z. Studium procesu spalania gazu w dwupaliwowym silniku o zapłonie samoczynnym zasilanym gazem ziemnym i olejem napędowym. Wydawnictwo ATH, Praca habilitacyjna, Bielsko-Biała 2003.

[17] STELMASIAK, Z. Dwupaliwowe silniki o zapłonie samoczynnym. Wydawnictwo Naukowe Instytutu Technologii Eksploatacji. Radom 2013.

[18] STELMASIAK, Z. Impact of engine control on the energetic interchangeability of diesel oil by gas in dual fuel CI engine. Journal of KONES Powertrain and Transport. 2013, 20(1), 425-434.

[19] STELMASIAK, Z., LARISCH, J. Dwupaliwowe zasilanie silnika Fiat 1.3 MultiJet. Logistyka. 2014, 6.

[20] STELMASIAK, Z., LARISCH, J., PIETRAS, D. Wpływ dodatku gazu ziemnego na zadymienie spalin samochodowego silnika ZS. Combustion Engines. 2015, 3.

[21] STELMASIAK, Z., LARISCH, J., PIETRAS, D. Wpływ dodatku gazu ziemnego na wybrane parametry pracy silnika Fiat 1.3 MultiJet zasilanego dwupaliwowo. Combustion Engines. 2015, 3 .

[22] STELMASIAK, Z., LARISCH, J., PIETRAS, D. Wybrane problemy adaptacji samochodowego silnika o zapłonie samoczynnym do zasilania dwupaliwowego. Combustion Engines. 2015, 3.

[23] STELMASIAK, Z., LARISCH, J., PIETRAS, D. Some problems of controlling the car diesel engine powered dual fuel. Combustion Engines no. 3/2015 (162) pp. 1070-1081.

[24] Materiały firmy FIAT AUTO POLAND, 2014.

[25] Materiały techniczne firmy EuropeGAS, 2013.

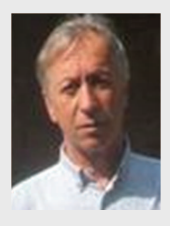

Dariusz Pietras, DEng. - Faculty of Mechanical Engineering and Computer Science at University of Bielsko-Biala.

e-mail:Pietras@ath.bielsko.pl



